\title{
Elektroniczna edycja rejestrów poborowych województwa kaliskiego z drugiej połowy XVI w.
}

\section{Michał Gochna}

Od wielu lat rejestry poborowe wykorzystywane są w pracach nad rekonstrukcją osadnictwa Polski w drugiej połowie XVI w. prowadzonych w Zakładzie Atlasu Historycznego Instytutu Historii Polskiej Akademii Nauk ${ }^{1}$. Jest to najlepsze źródło o charakterze masowym, które można wykorzystać do tego typu badań. Dotychczas nie decydowano się na wydawanie rejestrów używanych przy opracowaniu poszczególnych tomów Atlasu historycznego Polski. Obecnie, w ramach prac nad kolejnym tomem Atlasu, dotyczącym Wielkopolski, edycja taka została przygotowana. Oryginalność tego przedsięwzięcia polega jednak nie na samym fakcie realizacji edycji, ale na tym, że jest to edycja elektroniczna $\mathrm{z}$ wolnym dostępem $\mathrm{dla}$ użytkownika, zrealizowana przy użyciu oprogramowania GIS i pozwalająca na konfrontację wyników pracy edytorów z udostępnionym oraz dołączonym do niej skanem źródła. Co więcej, przy użyciu zastosowanej przy jej opracowywaniu metody, możliwe jest wydawanie rejestrów poborowych z całego obszaru I Rzeczypospolitej w różnych przedziałach czasowych. Dokonując odpowiednich modyfikacji tejże metody można ją także wykorzystać do edycji innych źródeł, nie tylko skarbowych (oprócz rekognicjarzy albo rejestrów pogłównego lub podymnego mogą to być np. wizytacje). Zanim jednak

\footnotetext{
1 Województwo płockie około 1578 r., red. S. Herbst, Warszawa 1958 (Atlas historyczny Polski. Seria A: Mapy szczegółowe, 2); Prusy Królewskie w drugiej połowie XVI wieku, oprac. M. Biskup, L. Koc, red. S. Herbst, Warszawa 1961 (Atlas historyczny Polski. Seria B: Mapy przeglądowe, 1); Województwo lubelskie w drugiej połowie XVI wieku, red. W. Pałucki, oprac. S. Wojciechowski, Warszawa 1966 (Atlas historyczny Polski. Mapy szczegółowe XVI wieku, 3); Mazowsze w drugiej połowie XVI w., red. W. Pałucki, Warszawa 1973 (Atlas historyczny Polski. Mapy szczegółowe XVI wieku, 7); Województwo sandomierskie w drugiej połowie XVI w., red. W. Pałucki, Warszawa 1993 (Atlas historyczny Polski. Mapy szczegółowe XVI wieku, 2); Województwo sieradzkie i województwo tęczyckie $w$ drugiej połowie XVI w., red. H. Rutkowski, Warszawa 1998 (Atlas historyczny Polski. Mapy szczegółowe XVI wieku, 5); Województwo krakowskie w drugiej
}

przedstawię specyfikę i sposób funkcjonowania edycji elektronicznej, chciałbym skupić się na krótkiej charakterystyce samego źródła, czyli rejestrach poborowych województwa kaliskiego $\mathrm{z}$ drugiej połowy XVI w.

Proces powstawania rejestrów wiąże się ściśle z obradami sejmu Rzeczypospolitej. Zebrana na sejmie szlachta uchwalała pobór podatku $\mathrm{z}$ przeznaczeniem na cele wojenne. Wydawano odpowiedni dokument - zwany uniwersałem - zawierający m.in. wykaz stawek podatkowych, jakimi objęte były poszczególne kategorie. Pod pojęciem kategorii podatkowej należy tu rozumieć rodzaj dóbr obłożony podatkiem w wysokości dokładnie oznaczonej lub przybliżonej, albo $\mathrm{w}$ ogóle z płacenia podatku zwolniony ${ }^{2}$. Kategorie te podzielić można w pewnym uproszczeniu na trzy główne grupy. Pierwszą z nich stanowity te odnoszące się do areału uprawnego, jak łan kmiecy, sołtysi, folwarczny lub pusty. Do drugiej zaliczyć można wszelkiego rodzaju obiekty gospodarcze: karczmy, młyny, wiatraki i in. W skład trzeciej grupy wchodzity kategorie zawodowe i społeczne takie jak rzemieślnicy, zagrodnicy, komornicy, rataje $\mathrm{i}$ in. Naturalnie każdy uniwersał posiadał własną specyfikę. Stawki podatkowe w nich zawarte obejmowały różne kategorie, w zależności od podjętych na danym sejmie uchwał. Dlatego

połowie XVI w., red. H. Rutkowski, Warszawa 2008 (Atlas historyczny Polski. Mapy szczegółowe XVI wieku, 1).

$2 \mathrm{~W}$ uniwersale z $1565 \mathrm{r}$. podano m.in. precyzyjne stawki podatku dla poszczególnych rodzajów zagrodników i rzemieślników (,Zagrodnicy, ktorzy ku zagrodom role maią, płacić maią po cztery grosze; Rzemiestnicy na wsiach, od rzemiesła po dwu groszu") oraz przyblizone dla komorników w mniejszych miastach („W miasteczkach podleiszych po siedmi groszy, a maią wszędy mieć baczenie na ubostwo"). Wskazano także na zwolnienie z podatku wsi pustych od czterech lat (,Wsi spustoszałe, spalone od lat czterech, a nie więcej, ktore nie płaca czynszow panom swym, takowe wolne maią bydź od płacenia"), Volumina Constitutionum, t. 2 (1550-1609), vol. 1 (1550-1585), przyg. S. Grodziski, I. Dwornicka, W. Uruszczak, Warszawa 2005, s. $186-187$. 
też każdy uniwersał zawierał nieco inny zestaw kategorii podatkowych (np. w 1565 r. podatkiem objęte zostały karczmy, a w 1578 r. tylko lany karczemne) ${ }^{3}$.

Oprócz stawek podatkowych uniwersały zawierały również wykaz poborców wraz ze swego rodzaju instrukcją zbierania podatku. W jej ramach na ogół podawano obszar, jaki podlegał każdemu poborcy, przedstawiano sposób przeprowadzania poboru i wyznaczano terminy oraz sposób rozliczania się z zebranych pieniędzy.

Po zakończeniu obrad sejmowych uniwersały były rozsyłane po terytorium całego kraju tak, aby jak największa liczba osób mogła się zapoznać z ich treścią. Kopie uniwersałów sporządzano w kancelariach grodzkich, rozsyłano je również do kościołów parafialnych, gdzie były publicznie odczytywane. Dzięki temu informacja o poborze trafiała do szerokiego kręgu odbiorców w miastach i wsiach ${ }^{4}$.

Zajmujący się zbieraniem podatku poborca, wraz z zatrudnionymi przez siebie osobami, organizował kancelarię, w której przyjmował odpowiednie wpłaty. Płatnikiem była przeważnie osoba będąca właścicielem wsi lub jej działu, a w miastach przedstawiciel władz. Najczęściej płatnik delegował w swoim imieniu zaufaną osobę. Gdy płatnik, bądź jego przedstawiciel, dokonywał opłaty podatkowej, poborca fakt ten odnotowywał w prowadzonym przez siebie rejestrze wpłat. Podobna procedura stosowana była przy każdej wpłacie. Wszystkie zapisy tworzyły razem rejestr poborowy dla danego powiatu. Porównanie rejestrów $\mathrm{z}$ odpowiednimi uniwersałami wskazuje na zgodność stawek zebranego podatku ze stawkami wyznaczonymi $\mathrm{w}$ uniwersale. Wszelkie odstępstwa od tej normy, a więc inne kwoty w rejestrze od tych zawartych w uniwersale, informują o faktycznym stanie danej kategorii w poszczególnych wsiach (np. ściągnięcie od zagrodnika czy komornika podatku niższego od najniższej stawki przeznaczonej dla tych grup społecznych świadczyć może o jego ubóstwie).

\footnotetext{
3 Tamże, s. 186, 423; K. Boroda., Kmieć, łan czy profit? Co było podstawą poboru łanowego w XV i XVI wieku? w: Człowiek wobec miar i czasu w przeszłości, red. P. Guzowski, M. Liedke, Warszawa 2007, s. $168-170$.
}

Jeden rejestr poborowy obejmował wpłaty podatku ze wsi leżących w granicach jednego powiatu skarbowego. W przypadku rejestrów poborowych województwa kaliskiego z drugiej połowy XVI w., ze względu na ich formę, wyróżnić można dwa rodzaje rejestrów: tekstowotabelaryczny i tabelaryczny. W obu formach miejscowości, ze względów praktycznych, grupowano w parafie. Te zaś umieszczano najczęściej w porządku alfabetycznym.

W przeważających liczebnie rejestrach tekstowo-tabelarycznych na środku strony wpisywano większymi literami nazwę miejscowości. Jeśli była to miejscowość parafialna, dodawano obok nazwy literę „P.” bądź skrót „Par.” (łac. parochia). Poniżej nazwy znajdował się spis kategorii podatkowych wraz z liczbą jednostek w każdej z nich w danej miejscowości lub dziale. Niekiedy po prawej stronie listy kategorii wpisywano stawki podatku, jakimi były one objęte. Na prawo od tego zapisu umieszczano zazwyczaj sumę zebranego podatku ze wsi, działu bądź kilku działów, wyrażoną we florenach (złotych polskich) i groszach, a czasami również w denarach.

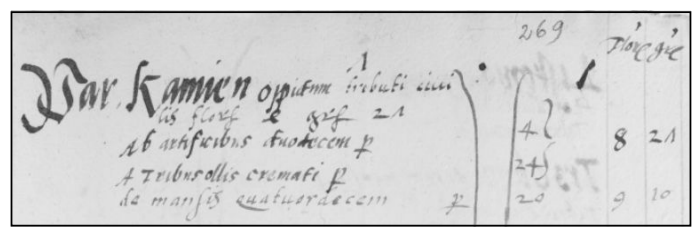

Ryc. 1. Fragment rejestru poborowego powiatu nakielskiego z 1565 r. Źródło: AGAD, ASK I 5, k. 269

W przypadku rejestrów tabelarycznych, w których, jak sama nazwa wskazuje, rysowano wiersze i kolumny tworzące tabele, w jednym wierszu umieszczano zapis dotyczący jednej miejscowości. Pierwsza kolumna od lewej zawierała nazwy miejscowości. W górnym wierszu znajdowały się nazwy poszczególnych kategorii podatkowych. W ostatnich

\footnotetext{
${ }^{4}$ K. Chłapowski, Rejestry poborowe województwa kaliskiego z XVI wieku. Wstęp, w: Atlas historyczny Polski. Rejestry poborowe województwa kaliskiego w XVI w. red. M. Słoń, Instytut Historii PAN 2013(http:// www.atlasfontium.pl, dostęp: 20 maja 2014).
} 
dwóch kolumnach po prawej stronie karty umieszczano sumy podatku. Dzięki temu poborca wpisywał jedynie liczby w kolumnach odpowiadających określonym kategoriom podatkowym i nie musiał, jak to było w przypadku rejestrów tekstowo-tabelarycznych, wpisywać przy każdej miejscowości nazw tychże kategorii. Również i w tym typie rejestrów dodawano odpowiednią adnotację na oznaczenie miejscowości parafialnej.

Prace nad edycją rejestrów poborowych województwa kaliskiego z drugiej połowy XVI w. rozpoczęto od stworzenia bazy danych z informacjami pochodzącymi z rejestrów. W związku z tym dane $\mathrm{z}$ rejestrów wpisano do arkuszy kalkulacyjnych $\mathrm{w}$ popularnym formacie .xls. W takim kształcie jeden arkusz odpowiada jednemu rejestrowi, a jedna zapiska źródłowa, dotycząca konkretnej miejscowości albo jej działu, przypada na jeden wiersz arkusza. W całej bazie danych daje to sumę ponad 20 tysięcy rekordów, przy czym jeden rekord rozumie się jako jeden wiersz w tabeli.

Kolumny w arkuszach można podzielić na dwie grupy. Pierwszą stanowią kolumny techniczne, występujące we wszystkich rejestrach (oprócz kolumny „Data”) i zawierające informacje służące do identyfikacji zapiski. Są to kolumny:

- identyfikator miejscowości (unikalny dla każdej miejscowości, składający się z jej nazwy oraz skrótów oznaczających województwo, powiat i ewentualnie parafię)

- rok powstania rejestru poborowego

- data dzienna zainkasowania opłaty (tylko w niektórych rejestrach)

- sygnatura archiwalna rejestru (odpowiedni dział i tom Archiwum Skarbu Koronnego - obecnie w Archiwum Głównym Akt Dawnych w Warszawie)

- numer strony lub karty rejestru

- numer kolejny zapiski źródłowej (numer rekordu)

- hiperłącze do skanu rękopisu dostępnego na stronie internetowej

- varia (kolumna techniczno-źródłowa: niestandardowe zapisy źródłowe, uwagi autora edycji $i$ in.)
Z kolei druga grupa kolumn, gdzie wpisane zostały informacje źródłowe o poszczególnych kategoriach podatkowych, dostosowana została każdorazowo do konkretnego rejestru. Jest to spowodowane faktem, że źródła te różnią się od siebie i zawierają różnorodny zasób informacji. Wynika to zarówno z liczby i rodzaju kategorii podatkowych objętych w danym roku podatkiem, jak i sposobu prowadzenia rejestru przez pisarza. Do kolumn źródłowych zaliczyć można te, w których zawarte są informacje np. o obiektach, łanach, rzemieślnikach, zagrodnikach i in.

Podczas prac edytorskich oprócz rejestrów poborowych wykorzystano także pozostałe źródła, takie jak lustracje królewszczyzn, wizytacje parafialne i inwentarze starostw. Dzięki temu możliwe było uzyskanie informacji na temat miejscowości występujących w rejestrach, a także uchwycenie osad, które w rejestrach nie zostały odnotowane ${ }^{5}$. Szczególnie cennym źródłem były wizytacje parafialne, które posłużyły do określenia przynależności parafialnej danych miejscowości.

$\mathrm{Na}$ podstawie informacji pozyskanych ze wspomnianych źródeł stworzone zostały tabele zbiorcze dla każdego powiatu. Zawierają one dane ustalone przez badacza o poszczególnych osadach w II połowie XVI w. Informacje te umieszczone zostały w kolumnach: identyfikator miejscowości, nazwy miejscowości (nazwa współczesna, nazwa szesnastowieczna ustalona przez badacza, odmianki nazwy szesnastowiecznej, nazwa ustalona przez zespół Stownika historyczno-geograficznego ziem polskich $w$ średniowieczu ${ }^{6}$ ), charakter osady (wieś, miasto, inny), własność (szlachecka, królewska, duchowna, inna), nazwa parafii, ważniejsze obiekty, wielkość osady, varia (komentarze) i inne. Tabele zbiorcze i arkusze z rejestrami stanowią główną część bazy danych.

Równolegle $\mathrm{z}$ tworzeniem bazy danych prowadzono prace nad stworzeniem mapy województwa kaliskiego. Do tego celu wykorzystane

\footnotetext{
5 Wiarygodność i przydatność rejestrów poborowych jako źródeł skarbowych do dziejów osadnictwa była i jest wciąż dyskutowana w literaturze przedmiotu, zob. K. Chłapowski, Rejestry poborowe.

6 Zob. Stownik historyczno-geograficzny ziem polskich w średniowie$c z u$, red. T. Jurek (http://www.slownik.ihpan.edu.pl, dostęp: 20 maja 2014).
} 
zostało oprogramowanie ArcGIS firmy ESRI. Powstały w ten sposób w postaci wektorowej warstwy topograficzne i fizjograficzne, przedstawiające rzeki, jeziora, bagna i lasy. Sporządzono również warstwę zawierającą granice administracyjne województwa i leżących w nim sześciu powiatów. Najistotniejszą jednak była warstwa punktowa, obejmująca miejscowości istnieją- netowej oraz w postaci przygotowanych do pobrania plików (o czym niżej).

Całość projektu znajduje się $\mathrm{w}$ witrynie „Atlas Źródeł i Materiałów do Dziejów Dawnej Polski" ". Jest to serwis otwarty, służący zarówno historykom, jak i badaczom innych dziedzin, do publikacji wyników badań i elektronicznych edycji źródłowych. Obecnie znaj-

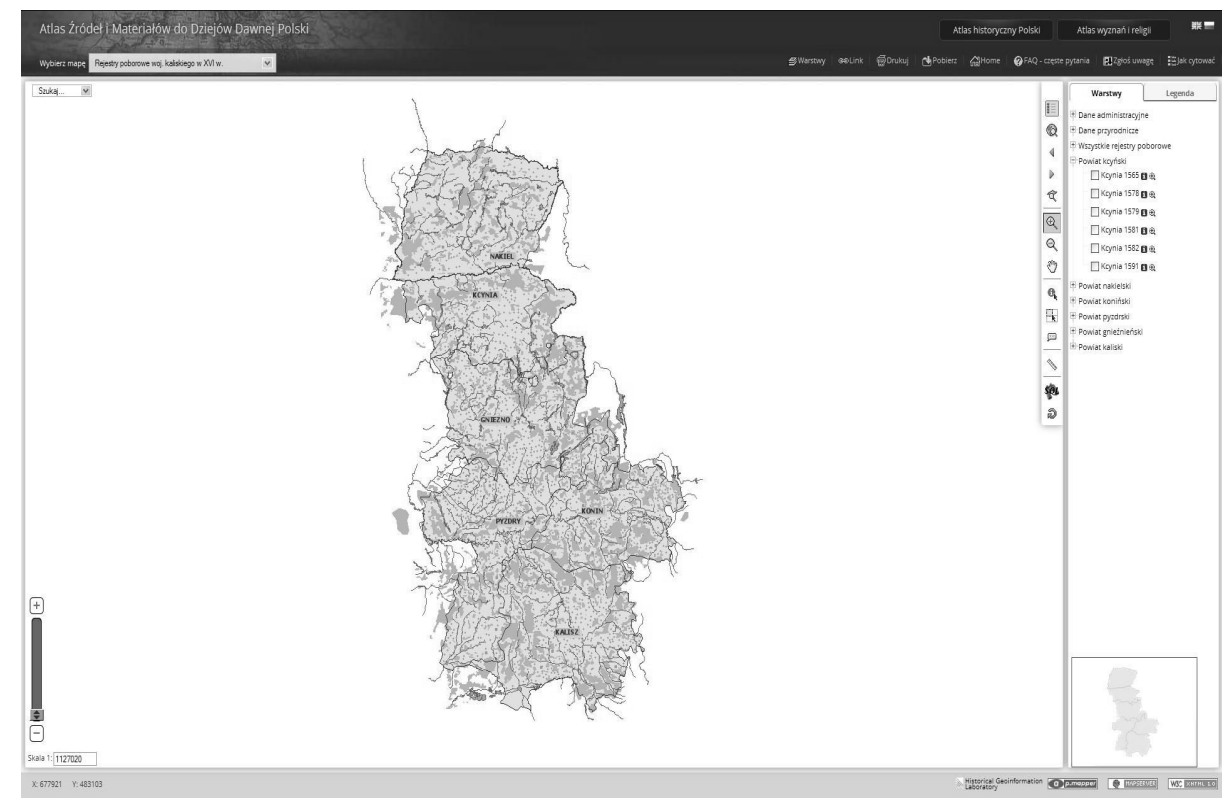

Ryc. 2. Rejestry poborowe województwa kaliskiego w XVI wieku w witrynie „Atlas Źródet i Materiałów do Dziejów Dawnej Polski" (http://www.atlasfontium.pl, dostęp: 20 maja 2014)

ce na danym terenie w II połowie XVI w. By takową stworzyć, oprócz wspomnianych wyżej źródeł, wykorzystano dawne mapy obejmujące swym zasięgiem badany obszar. Za podstawę użyto map Wojskowego Instytutu Geograficznego, ze względu na ich dokładność i bogactwo informacyjne. Sięgano również do map z drugiej połowy XVIII w. i późniejszych. Na podstawie stworzonej warstwy z osadami, narysowane zostały również przybliżone granice parafii.

Kolejnym krokiem w przygotowaniu edycji było połączenie danych $\mathrm{z}$ rejestrów $\mathrm{z}$ odpowiednimi warstwami wektorowymi. Otrzymano w ten sposób przestrzenną bazę danych. Jej udostępnianie odbywa się na dwa sposoby - poprzez aplikację WebGIS na stronie inter- dują się tam trzy publikacje: Rejestry poborowe województwa kaliskiego w XVI wieku, będąca przedmiotem niniejszego artykułu, Wschowska księga grodzka, 1496-1526 (edycja elektroniczna), opracowana przez zespół pod kierunkiem Marka Słonia ${ }^{8}$, oraz mapa Religie

\footnotetext{
7 „Atlas Źródeł i Materiatów do Dziejów Dawnej Polski”, ISSN 23539216 (http://www.atlasfontium.pl, dostęp: 20 maja 2014).

8 Obie elektroniczne edycje źródłowe - rejestrów poborowych woj. kaliskiego z drugiej połowy XVI w. oraz wschowskiej księgi grodzkiej z lat 1496-1526 - otwierają szerokie pole do dyskusji nad wykorzystaniem nowoczesnych narzędzi w edycji źródeł historycznych. Istotne jest tu przede wszystkim wykorzystanie dotychczasowego dorobku edytorstwa historycznego przy opracowywaniu edycji elektronicznych, jak też wypracowanie odpowiednich metod, które pozwolą na najbardziej wszechstronne użycie nowoczesnych narzędzi. Zagadnienie to jest jednak zbyt obszerne, by mogło zostać omówione w ramach niniejszego artykułu.
} 
i wyznania w Koronie w II potowie XVIII wieku, przygotowana przez Bogumiła Szadego.

Po wejściu na stronę projektu Rejestry poborowe województwa kaliskiego w XVI wieku użytkownik przechodzi do aplikacji WebGIS, gdzie może przeszukiwać przestrzenną bazę danych i dokonywać prostych analiz przestrzennych i statystycznych. Możliwe jest wyświetlanie danych pochodzących $\mathrm{z}$ jednego bądź wszystkich rejestrów poborowych. Przy aktywnych warstwach „Miejscowości” oraz "Wszystkie rejestry poborowe” użytkownik otrzymuje komplet dostępnych $\mathrm{w}$ aplikacji informacji źródłowych, odnoszących się do wszystkich osad występujących w objętych edycją rejestrach poborowych. Są to dane po- odpowiedzialnej za przygotowanie rejestrów dotyczących danego powiatu i, po uznaniu zasadności uwagi, błąd jest poprawiany. Dzięki temu istnieje duże prawdopodobieństwo, że z biegiem czasu ewentualne niedociągnięcia edycji zostaną wyeliminowane.

Informacje o projekcie i jego poszczególnych składnikach użytkownik może odnaleźć na kilka sposobów. Podstawowe objaśnienia dostępne są na stronie głównej „Atlasu Źródeł i Materiałów...”. Odpowiedzi na najczęściej zadawane pytania można odnaleźć w zakładce FAQ (Frequently Asked Questions). Wiadomości o konkretnych warstwach uzyskuje się po kliknięciu na daną warstwę prawym przyciskiem myszy, a dalej na „Informacje o warstwie”.

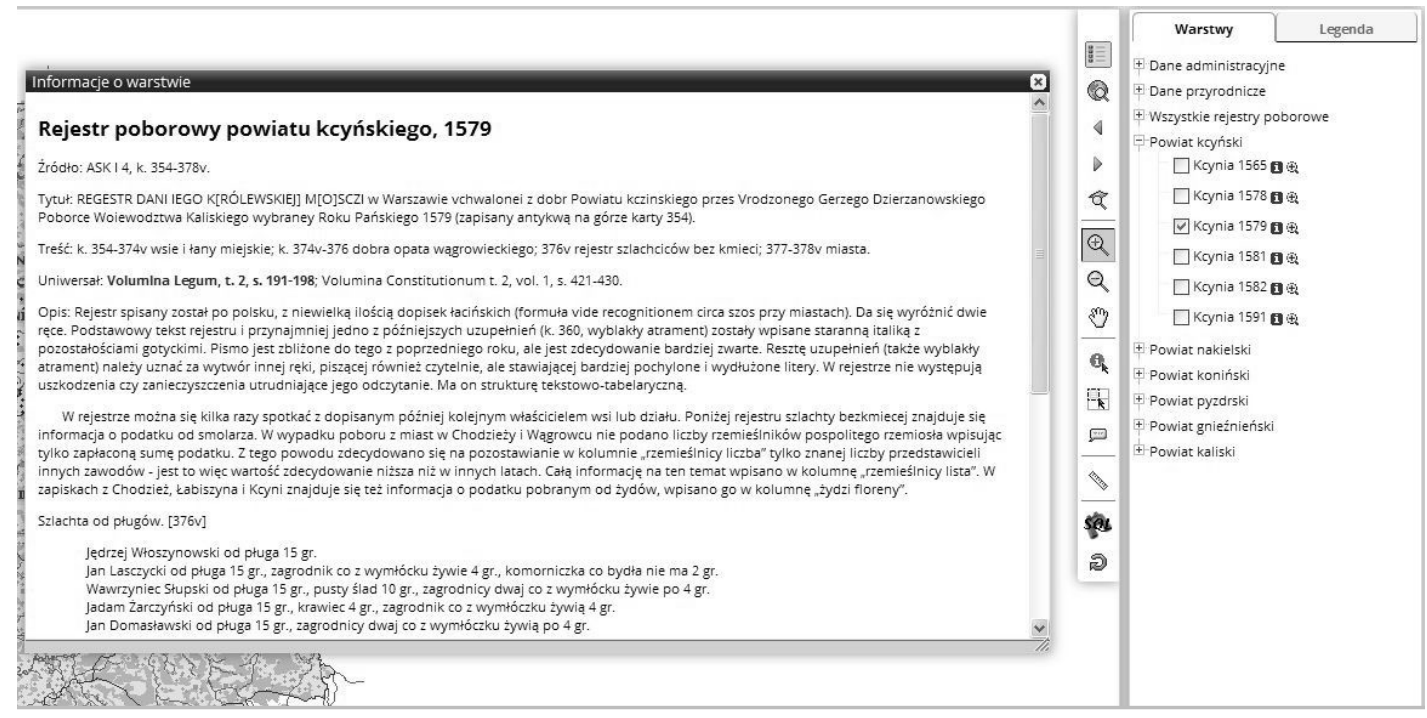

Ryc. 3. Informacje o rejestrze poborowym powiatu kcyńskiego z 1579 r.

chodzące z tabeli zbiorczej, jak też te, które pochodzą z umieszczonych na stronie spisów podatkowych. Istotnym elementem projektu jest możliwość konfrontacji odczytanych przez badacza danych ze skanami rękopisu, które są wyświetlane po kliknięciu na numer strony lub karty zawierającej określony zapis źródłowy. Jeśli użytkownik zauważy błąd w edycji, ma możliwość jego zgłoszenia używając formularza "Zgłoś uwagę". Po wypełnieniu formularza informacja o błędzie trafia do osoby
Z kolei wiadomości o konkretnym rejestrze poborowym uzyskać można klikając na ikonkę obok jego nazwy.

Wyszukiwanie informacji w bazie danych odbywa się na dwa sposoby. Pierwszym z nich jest wyszukiwanie proste, które pozwala na szybkie odnalezienie np. osady, przyjmując za kryterium jej nazwę. Wyszukiwarka ta odnajduje ciąg znaków w dowolnej pozycji w słowie. Przykładowo szukając miejscowości Smolice, po wpisaniu do wyszukiwarki wyrażenia 
„mol” pokażą się nazwy miejscowości zawierające w sobie ciąg znaków „mol” (np. Smolina, Smolnik, Biskupice Smolczane, Kromolice). Niezmiernie istotny jest fakt, że wyszukiwanie obejmuje różne nazwy: współczesną, nazwę przyjętą przez zespół Stownika historycznogeograficznego ziem polskich $w$ średniowieczu, szesnastowieczną oraz jej odmianki. Dzięki temu użytkownik nie musi znać dawnej nazwy, wystarczy, że wpisze obecną nazwę miejscowości.

Drugą metodą przeszukiwania danych w aplikacji WebGIS jest kreator zapytań SQL. Obejmuje on wyszukiwanie według wielu atrybutów. Istnieje również możliwość wyszukiwania poprzez łączenie różnych atrybutów (np. łany kmiece i parafia - w prosty sposób można odnaleźć miejscowości z parafii X posiadające określoną liczbę łanów czy też osady należące do konkretnej osoby). Wyniki wyszukiwania można zapisać i pobrać $\mathrm{w}$ postaci plików $\mathrm{w}$ formacie.$x l s$, .csv lub .pdf.
Oprócz przeglądania danych $\mathrm{w}$ aplikacji WebGIS istnieje możliwość pobrania odpowiednich plików. Wśród nich znajdują się: geobaza osobista w formacie .mdb zawierająca wszystkie warstwy (bagna, jeziora, lasy, osady, granice parafii, granice powiatów, rzeki), pliki $\mathrm{w}$ formacie $x l s \mathrm{z}$ arkuszami rejestrów poborowych i tabelą zbiorczą oraz plik .xls zawierający objaśnienie nazw kolumn w arkuszach. Dane można poddać analizom na dwóch poziomach: arkuszy kalkulacyjnych i oprogramowania GIS Pracując z GIS użytkownik ma możliwość przede wszystkim szybkiego tworzenia własnych map (np. młynów i wiatraków, karczem, rozkładu łanów kmiecych i in.). Posiadając całą bazę danych jest on w stanie przeprowadzać dowolne analizy w zależności od potrzeb.

Edycja skierowana jest do szerokiego grona użytkowników. Korzystać z niej mogą zarówno naukowcy, wykorzystujący w swoich badaniach edycje źródłowe, jak również wszelkie osoby zainteresowane historią, $\mathrm{m}$. in. regionaliści

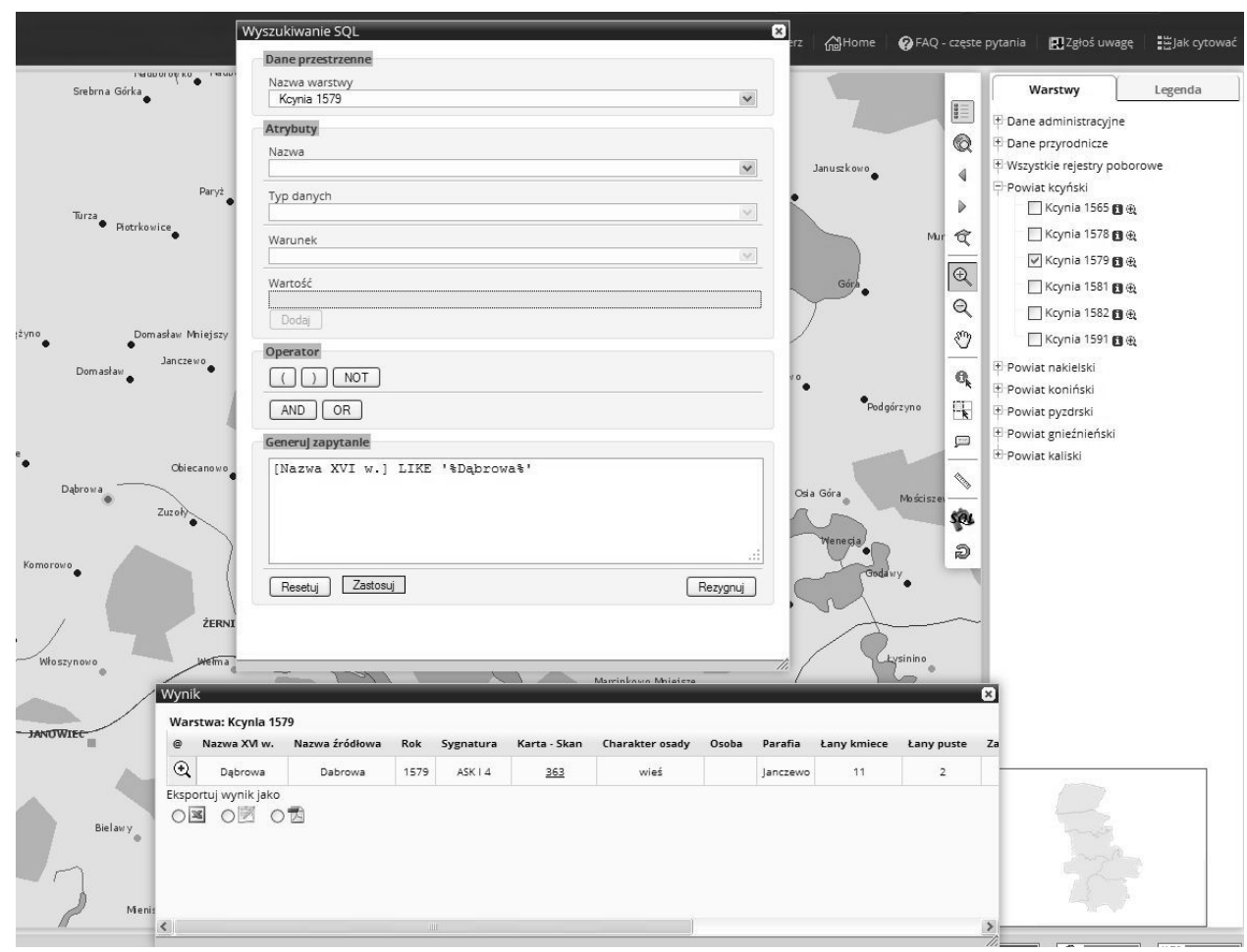

Ryc. 4. Wyszukiwanie przy pomocy kreatora zapytań SQL 
i genealodzy. Należy pamiętać, że aplikacja jest otwarta na użytkownika i jego głos krytyczny. Dostęp do skanu rękopisu i weryfikacja ewentualnych błędów powoduje aktywne, choć może nie zawsze na wielką skalę, włączenie się użytkownika w jej rozwój. Można stwierdzić, że edycja ta wpisuje się w pewnym sensie w nurt coraz bardziej popularnych działań w obszarze „otwartej nauki” (Open Science). Istotny jest również fakt, że edycja jest udostępniana za darmo i dostęp do niej ma każda zainteresowana osoba posiadająca urządzenie podłączone do Internetu. Jest to tym samym nie tylko forma publikacji wyników badań, ale zarazem sposób ich popularyzacji.

Niewątpliwą zaletą edycji jest możliwość integracji danych z innymi tego typu projektami. Planowane jest dodanie do nazw miejscowości hiperłączy odsyłających użytkownika do odpowiedniego hasła na stronie Stownika historyczno-geograficznego ziem polskich w średniowieczu. Być może w przyszłości uda się w formie internetowej udostępnić wydane do tej pory tomy Polskiego Stownika Biograficznego, co pozwoli-

\section{Literatura}

Źródła wydane drukiem

Volumina Constitutionum, t. 2 (1550-1609), t. 1: (1550-1585), przyg. S. Grodziski, I. Dwornicka, W. Uruszczak, Warszawa 2005.

\section{Literatura przedmiotu}

Województwo krakowskie $w$ drugiej potowie $X V I$ w., red. H. Rutkowski, Warszawa 2008 (Atlas historyczny Polski. Mapy szczegółowe XVI wieku, 1).

Województwo sandomierskie $w$ drugiej potowie $X V I$ w., red. W. Pałucki, Warszawa 1993 (Atlas historyczny Polski. Mapy szczegółowe XVI wieku, 2).

Województwo sieradzkie i województwo tęczyckie $w$ drugiej potowie XVI w., red. H. Rutkowski, Warszawa 1998 (Atlas historyczny Polski. Mapy szczegółowe XVI wieku, 5).

Mazowsze w drugiej potowie XVI w., red. W. Pałucki, Warszawa 1973 (Atlas historyczny Polski. Mapy szczegółowe XVI wieku, 7). łoby na połączenie danych z rejestrów z danymi biograficznymi. Podobnie można byłoby postąpić ze Spisami urzędników dawnej Rzeczypospolitej po ich uprzednim zdigitalizowaniu?.

Elektroniczna edycja rejestrów poborowych województwa kaliskiego z drugiej połowy XVI w. jest pierwszym przedsięwzięciem edycyjnym o tego typu metodzie w Polsce. Podczas jej przygotowania wiele czasu poświęconego zostało na opracowanie odpowiedniej metodologii tak, by połączyć dotychczasowe ustalenia edytorstwa źródeł historycznych z nowymi technologiami. Aby tego typu inicjatywy mogły się rozwijać, niezbędne staje się wypracowanie pewnych standardów, którymi mogliby posługiwać się badacze decydujący się na realizowanie podobnych projektów. Duże zainteresowanie w środowisku historyków tą formą przedstawiania wyników swoich badań czy też publikacji źródeł, pozwala mieć nadzieję, że zasób danych źródłowych dostępnych w Internecie, powiązanych ze sobą i opracowanych przez profesjonalnych badaczy, będzie się stale powiększał.

Województwo lubelskie w drugiej potowie XVI wieku, red. W. Pałucki, oprac. S. Wojciechowski, Warszawa 1966 (Atlas historyczny Polski. Mapy szczegółowe XVI wieku, 3).

„Atlas Źródeł i Materiałów do Dziejów Dawnej Polski” (http://www.atlasfontium.pl, dostęp: 20 maja 2014).

Boroda K., Kmieć, tan czy profit? Co byto podstawa poboru tanowego w XVI i XVI wieku?, $\mathrm{w}$ : Cztowiek wobec miar $i$ czasu w przesztości, red. P. Guzowski, M. Liedke, Warszawa 2007, s. 152-170.

9 Urzędnicy dawnej Rzeczypospolitej XII-XVIII wieku. Spisy, pod red. A. Gąsiorowskiego, Instytut Historii PAN 1985- [wiele tomów]. 
Chłapowski K., Rejestry poborowe województwa kaliskiego z XVI wieku. Wstęp, w: Atlas historyczny Polski. Rejestry poborowe województwa kaliskiego $w X V I w$., red. M. Słoń, Instytut Historii PAN 2013- (http://www.atlasfontium.pl, dostęp: 20 maja 2014).

Prusy Królewskie w drugiej potowie XVI wieku, oprac. M. Biskup, L. Koc, red. S. Herbst Warszawa 1961 (Atlas historyczny Polski. Seria B: Mapy przeglądowe, 1).
Stownik historyczno-geograficzny ziem polskich $w$ średniowieczu, red. T. Jurek (http://www. slownik.ihpan.edu.pl, dostęp: 20 maja 2014).

Urzędnicy dawnej Rzeczypospolitej XII-XVIII wieku. Spisy, red. A. Gąsiorowski, Instytut Historii PAN 1985- [wiele tomów].

Województwo ptockie okoto 1578 r., red. S. Herbst, Warszawa 1958 (Atlas historyczny Polski. Seria A: Mapy szczegółowe, 2).

\section{Electronic edition of historical sources of tax registers of the Kalisz voivodeship in the second half of 16 th century}

\section{Summary}

The paper describes how GIS was used to prepare the electronic edition of historical sources of tax registers of the Kalisz voivodeship in the second half of 16th century. Source data from the tax registers were typed out into spreadsheets. Different sources, like parochial visitations, king's domain's inspections and others, were used to obtain information about the settlements that was omitted in tax registers. Simultaneously, topographical and physiographical layers (forests, swamps, rivers, lakes, borders of voivodeships and districts, later - borders of parishes) were prepared in GIS. By using the data from tax registers and old maps the map of settlements was developed. Connecting the GIS layers with the data from the tax registers we created a spatial database. This database is available for all persons interested at the „Atlas of sources and materials for history of old Poland" website. The users can work with it on the Internet, using the WebGIS application, or download all data on their computers. After that the data can be used by the user freely. Furthermore, the users have access to the scan of original manuscripts and, if they find an error in the edition, they can report it to the administrators. If the mistake is confirmed by one of the scientists, it will be corrected.

The described way of editing the historical sources is a new method for presenting the results of historical inquiries and editions of historical sources. The data from this edition can be related with the data from other projects. Those relations can make a database of historical data with a very high information potential that can be used in historical research.

Słowa kluczowe: GIS, rejestry poborowe, powiat kaliski, Atlas historyczny Polski, edycja źródłowa, Wielkopolska

Keywords: GIS, tax registers, Kalisz district, Historical Atlas of Poland, source edition, Wielkopolska region

mgr Michał Gochna - asystent w Zakładzie Atlasu Historycznego Instytutu Historii im. Tadeusza Manteuffla Polskiej Akademii Nauk. Prowadzi badania nad dziejami szlachty powiatu kaliskiego w XVI w. Interesuje się również nowożytnymi miastami prywatnymi oraz dziejami Mazowsza i Podlasia

(e-mail: mgochna@wp.pl) 